\title{
MODEL STORE ATMOSPHERE DAN KUALITAS PRODUK DALAM MEMBENTUK KEPUTUSAN PEMBELIAN KONSUMEN PADA GERAI J.CO DONUTS \& COFFEE DIKOTA JAMBI
}

\author{
Danil Muhlisin ${ }^{1)}$, Novita Ekasari ${ }^{2)}$ \\ ${ }^{1,2)}$ Prodi Manajemen FEB Universitas Jambi \\ muhlisindanil@gmail.com
}

\begin{abstract}
Abstrak
Penelitian ini berjudul "model store atmosphere dan kualitas produk dalam membentuk keputusan pembelian konsumen pada gerai J.CO Donuts \& Coffee di kota Jambi”. Tujuan dari penelitian ini adalah untuk mengetahui seberapa besar model store atmosphere dalam membentuk keputusan pembelian pada gerai J.CO Donuts \& Coffee di kota Jambi, seberapa besar pengaruh kualitas produk produk dalam membentuk keputusan pembelian pada gerai J.CO Donuts \& Coffee di kota Jamb, dan bagaimana pengaruh kedua variabel independen tersebut dalam membentuk keputusan pembelian pada gerai J.CO Donuts \& Coffee di kota Jambi. Pada penelitian ini dilakukan dengan metode regrensi berganda, dimana untuk mencapai tujuan pertama yaitu mengetahui model kedua variabel independennya. Regresi berguna dilakukan terhadap model lebih dari satu variabel bebas, untuk diketahu pengaruh terhadap variabel terkait. Hasil penelitian ini menunjukkan bahwa hasil variabel independen store atmosphere sebesar (0,072) yang mana artinya berpengaruh secara signifikan, sedangkan variabel independen kualitas produk nilai nya yaitu (0,595) artinya variabel independen kualitas produk berpengaruh secara signifikan dalam membentuk keputusan pembelian. Namu diantara dua variabel independen tersebut variabel yang paling mendominasi adalah variabel independen kualitas produk dimana nilainya lebih besar dibandingkan dengan nilai variabel independen store atmosphere.
\end{abstract}

Kata Kunci : store atmosphere, kualitas produk, keputusan pembelian

\begin{abstract}
This study is entitled "store atmosphere models and product quality in shaping consumer purchasing decisions at J.CO Donuts \& Coffee otlents in the city of Jambi". The porpose of this study was to determine how large the store atmosphere modes in shaping purchasing decisions at J.CO Donuts \& Coffee outlets in Jambi city, how much influence the quality of product products in shamping purchaising decisions at J.CO Donuts \& Coffee outlets in Jambi, and how the influence of these two independent variables in shaping purchasing decisions at J.CO Donuts \& Coffee outlets in the city of Jambi.in this study conducted with the multiple regression method in which to achieve the first goal that is to know the second models of the independent variables regression is useful for models of morethan one independent variables. The results of this study indicate that the results of the independent store atmosphere variable are $(0,072)$ which means that the significant variable product quality value $(0,595)$ means that the independent variable product quality significant influences the purchase decision. However, between the two independent variables the most dominating variable is the independent variable product quality where the value is greater thanwith the value of atmosphere store independent variable.
\end{abstract}

Key Word : store atmosphere, product quality, purchase decision 


\section{PENDAHULUAN}

Perkembangan perekonomian di Indonesia mengalami perubahan di segala bidang. Perubahan tersebut antara lain dipengaruhi oleh beberapa faktor diantaranya perubahan perilaku konsumen, kebijakan pemerintah, persaingan bisnis, perkembangan ilmu pengetahuan dan teknologi serta arus komunikasi yang berkembang semakin cepat. Perubahan dan perkembangan tersebut berjalan seiring dengan perkembangan kota-kota besar di Indonesia.

Pada kenyataannya, perkembangan dan perubahan di bidang ekonomi tersebut membawa akibat pada berbagai aspek dibidang ekonomi, termasuk terjadinya pergeseran manajemen dalam bidang pemasaran. Menurut Kotler dan Keller (2009), pergeseran dari berfokus pada transaksi yang mampu menghasilkan laba, berfokus pada nilai masa hidup pelanggan. Biasanya perusahaan akan mengarah pada menghasilkan laba pada masing masing transaksi. Namun, perusahaan modern lebih mengutamakan untuk berfokus pada pelanggan, produk, dan saluran mereka yang paling mampu menghasilkan laba. Mereka memperkirakan nilai masa hidup pelanggan individual dan merancang tawaran dan harga pasar untuk menghasilkan laba sepanjang hidup pelanggan.

Dalam beberapa tahun terakhir, bisnis kuliner dapat dikatakan mengalami peningkatan. Semakin banyak pebisnis atau investor yang membuka bisnis di bidang kuliner, seperti kafe, restoran, atau bahkan hanya membuka gerai di pinggir jalan. Jenis kuliner yang dijualpun kian beragam, mulai dari makanan atau minuman tradisional, modern, sampai kuliner khas negara lainpun tersedia.

Menurut hasil survei yang dilakukan oleh Badan Ekonomi Kreatif Indonesia (BEKRAF) yang bekerjasama dengan Badan Pusat Statistik (BPS) pada tahun 2018/2019, ekonomi kreatif mampu memberikan kontribusi secara signifikan terhadap pertumbuhan ekonomi nasional. Terutama pada subsektor kuliner yang memberikan kontribusi sebanyak $41,69 \%$

Para pebisnis kuliner tentunya melihat perubahan gaya hidup konsumen ini sebagai sebuah peluang, seperti yang dilakukan oleh salah satu perusahaan waralaba yang telah memiliki nama besar yaitu J.co donuts \& coffee. J.Co donuts \& coffee merupakan restoran dan waralaba yang mengkhususkan dalam donat, yogurt beku, dan kopi. J.co donuts \& coffee pertama kali dibuka pada 26 Juni 2005 di Supermal Karawaci, Tanggerang.

Kemunculan J.Co donuts \& coffee dinilai dapat menggeser Dunkin donuts yang telah menjadi penguasa pasar donat di Indonesia sejak 1985. Seperti yang dimuat oleh wartaekonomi.co.id, pada 9 Maret 2018 Warta Ekonomi mengadakan pemberian penghargaan kepada perusahaan-perusahaan yang dianggap memiliki pengaruh paling tinggi terhadap netizendi dunia maya, J.Co donuts \& coffee merupakan salah satu perusahaan yang mendapatkan penghargaan Netizen Brand Choice Award dengan menduduki peringkat ke-15 kategori tempat hangout-cafe dengan title Netizen cafe choice, disusul oleh Dunkin donuts dengan kategori dan title yang sama di peringkat ke-16.

Presentase top brand index Dunkin' donuts memang masih menempati posisi pertama, dan J.co donuts \& coffee menempati posisi kedua. Namun apabila dilihat dari nilai presentase keduanya, dari tahun 2018 ke tahun 2019 Dunkin donuts mengalami penurunan dari $51,7 \%$ menjadi $46,7 \%$ sedangkan J.co donuts \& coffee justru mengalami peningkatan yaitu dari 40,6\% menjadi 43,2\% selanjutnya Mister donuts dari 7,7\% menjadi $10,1 \%$ juga mengalami peningkatan, tetapi masih sangat jauh untuk bersaing. Perkembangan J.Co donuts \& coffee yang kian meningkat tidak lain karena J.Co donuts \& coffee merupakan restoran yang memperhatikan kenyamanan konsumennya. Dapat dilihat bahwa J.Co donuts \& coffee merupakan toko donat pertama di Indonesia yang 
menerapkan konsep dapur terbuka, sehingga para konsumen dapat melihat langsung pembuatan kue dan minuman yang akan mereka konsumsi. J.Co juga menampilkan suasana toko ala kafe yang sangat baik seperti sofa empuk, pendingin ruangan, juga akses internet nirkabel. Biasanya lokasi yang dipilih J.Co pun merupakan suatu tempat yang terdapat banyak orang seperti pusat kota ataupun pusat perbelanjaan/mall.

- Adanya perubahan gaya hidup masyarakat dapat dimanfaatkan oleh para produsen untuk meraup keuntungan semakin besar. Dalam menghadapi persaingan ini maka pengusaha yang bergerak dibidang makanan dan minuman atau Food dan Beverage (F dan B) berlomba-lomba menciptakan keunggulan untuk mendorong produknya tetap bertahan didalam persaingan yang semakin kompetitif. J.CO Donuts \& Coffee melakukan penataan ruang sebaik mungkin untuk menciptakan suasana Gerai yang nyaman saat konsumen menikmati hidangan yang dipesan dan produk yang bisa memuaskan pelanggan.

Selain store atmosphere, kualitas produk juga dapat menjadi pertimbangan konsumen untuk datang berkunjung. Dengan kualitas produk membuat konsumen akan tertarik untuk berkunjung. Kualitas produk yang ditawarkan akan menambah daya tarik konsumen untuk datang berkunjung karena mendapatkan produk makanan yang berkualitas sehingga konsumen mendapat rasa makanan yang enak sekaligus tempat yang nyaman akan membuat konsumen merasa terpuaskan hingga memunculkan minat untuk berkunjung kembali. Jika konsumen merasa puas, konsumen akan melakukan keputusan pembelian ulang. Maka dari itu perusahaan berusaha membuat konsumen puas dengan cara membangun store atmosphere yang bagus maupun dari kualitas produk yang baik.

\section{Tujuan Penelitian}

1. Untuk mengetahui dan menganalisis pengaruh Store Atmospere dan Kualitas produk terhadap Keputusan Pembelian Konsumen pada J.Co donuts \& coffe.

2. Untuk mengetahui variable manakah yang paling berpengaruh antara Store Atmospere dan Kualitas Produk terhadap keputusan pembelian konsumen pada J.co donuts \& coffee.

\section{TINJAUAN PUSTAKA}

\section{Store Atmosphere}

Atmosfir adalah elemen lain dalam melengkapi toko. Setiap toko mempunyai penampilan dan letak fisik yang bisa mempersulit atau mempermudah orang untuk bergerak. Sedangkan menurut Utami (2008) dalam Esti (2014), store atmosphere merupakan kombinasi dari karakteristik fisik seperti arsitektur, tata letak (display), pencahayaan, warna, temperatur, musik, serta aroma yang bertujuan meransang respon emosional dan persepsi pelanggan dan untuk mempengaruhi pelanggan dalam membeli barang atau produk.

Menurut Berman dan Evan (2014) terdapat elemen store atmosphere yang berpengaruh yang terditi dari Exterior, General Interior, Store Layout dan Interior Display. Adapun keempat elemen tersebut akan dijelaskan lebih lengkap sebagai berikut:

a. Exterior (Bagian Luar Toko)

Karakteristik exterior mempunyai pengaruh yang kuat pada citra toko tersebut, sehingga harus direncanakan dengan sebaik mungkin. Kombinasi dari exterior ini dapat membuat bagian luar toko menjadi terlihat unik, menarik, menonjol dan mengundang orang untuk masuk kedalam toko. 
b. General Interior ( Bagian Dalam Toko)

Paling utama yang dapat membuat penjualan setelah pembeli berada di toko adalah display. Desain interior dari suatu toko harus dirancang untuk memaksimalkan visual merchandising. Display yang baik yaitu dapat menarik perhatian pengunjung dan membantu mereka agar mudah mengamati, memeriksa dan memilih barang dan akhirnya melakukan pembelian.

c. Layout Ruangan (Tata Letak toko)

Pengelola toko harus mempunyai rencana dalam penentuan lokasi dan fasilitas toko. Pengelola toko juga harus memanfaatkan ruangan toko yang ada seefektif mungkin.

d. Interior Point of Interest Display (Dekorasi Pemikat Dalam Toko)

Interior point of interest display mempunyai dua tujuan, yaitu memberikan informasi kepada konsumen dan menambah store atmosphere ,hal ini dapat meningkatkan penjualan dan laba toko.

\section{Kualitas produk}

Menurut Kotler dan Armstrong (2004) "kualitas produk merupakan kemampuan suatu produk dalam melaksanakan fungsi dan kinerjanya yang dapat memenuhi kebutuhan dan keinginan pelanggan".

"Kualitas merupakan keseluruhan ciri dan sifat dari suatu produk atau jasa yang bergantung pada kemampuannya untuk dapat memuaskan kebutuhan yang diharapkan pelanggan" (Kotler dan Keller 2009). Kualitas dapat terpenuhi ketika perusahaan dapat memberikan produk sesuai dengan apa yang diharapkan pelanggan bahkan melebihi harapan pelanggan. Perusahaan yang menawarkan kualitas akan menciptakan hubungan baik dengan pelanggan. Hubungan baik yang sudah tercipta dalam jangka panjang akan membuat perusahaan mengerti terhadap kebutuhan yang diharapkan pelanggan. Hal seperti ini yang akan memberikan keuntungan positif bagi perusahaan.

Menurut Vincent Gaspersz (2011) dimensi-dimensi kualitas produk terdiri dari:

1. Kinerja (performance), yaitu karakteristik operasi pokok dari produk inti.

2. Ciri-ciri atau keistimewaan tambahan (features), yaitu karakteristik sekunder atau pelengkap.

3. Kehandalan (reliability), yaitu kemungkinan kecil akan mengalami kerusakan atau gagal pakai.

4. Kesesuaian dengan spesifikasi (conformance to specification), yaitu sejauh mana karakteristik desain dan operasi memenuhi standar-standar yang telah ditetapkan sebelumnya.

5. Daya tahan (durability), yaitu berkaitan dengan berapa lama produk tersebut dapat terus digunakan.

6. Serviceability, meliputi kecepatan, kompetensi, kenyamanan, mudah direparasi, penanganan keluhan yang memuaskan.

7. Estetika, yaitu daya tarik produk terhadap panca indera.

\section{Keputusan pembelian}

Menurut Kotler Dan Keller (2008), keputusan pembelian yang dilakukan oleh para konsumen melalui lima tahap yaitu: pengenalan kebutuhan, pencarian informasi, evaluasi alternative, keputusan pembelian, dan perilaku pasca pembelian. Jelaslah bahwa proses pembelian dimulai jauh sebelum pembelian actual dilakukan dan memiliki dampak yang lama setelah itu. Namun para para konsumen tidak selalu melewati seluruh lima urutan tahap ketika membeli produk 


\section{METODE PENELITIAN \\ Populasi Dan Sampel Penelitian}

Menurut sugiyono (2010), populasi adalah wilayah generalisasi yang terdiri dari subjek dan objek yang mempunyai karateristik dan kualitas tertentu untuk dipelajari kemudian ditarik kesimpulannya.

Sampel adalah bagian dari jumlah dan karakteristik yang dimiliki oleh populasi tersebut (Sugiyono 2016). Sampel dalam penelitian ini adalah konsumen J.co Donuts \& Coffe yang sudah pernah atau sudah beberapakali beli.

Menurut Hair dkk (2006) besaran sampel apabila terlalu besar akan menyulitkan untuk mendapat model yang cocok, dan disarankan ukuran sampel yang sesuai antara 100 - 200 responden. Akan tetapi bisa juga menggunakan teknik penentuan jumlah sampel sebagai berikut :

\section{Jumlah pertanyaan dalam kuesioner $X$ jumlah observed 24 item pertanyaan $X 5=120$}

Berdasarkan perhitungan jumlah penentuan sampel diatas, maka dipilih sampel sebanyak 130 responden konsumen yang pernah mengkonsumsi produk J.CO Donuts \& Coffee di Kota Jambi.

\section{Teknik Pengumpulan Data}

Teknik pengumpulan data untuk mendapatkan data-data ataupun informasi yang dibutuhkan dalam penelitian ini, maka peneliti menggunakan dua teknik pengumpulan data yaitu data primer dan skunder.

\section{Skala Pengukuran Variabel}

Skala pengukuran ini menggunakan skala likert untuk mengetahui skor pertanyaan. Skala likert merupakan skala yang dipakai untuk mengukur sikap, pendapat, dan persepsi seseorang/sekelompok orang tentang fenomena sosial (Juliandi, 2013). Penelitian ini menggunakan sejumlah statement skala 1-5 yang menunjukkan setuju atau tidak setuju terhadap statement tersebut.

\section{Analisis Regresi Linear berganda}

Alat regresi yang dimaksud untuk melihat sejauh mana Pengaruh Store atmosphere dan Kualitas produk dalam membentuk Keputusan Pembelian J.CO Donuts \& Coffee di Kota Jambi. Hipotesis penelitian akan diuji dengan menggunakan analisis regresi linier berganda. Analisis regresi linier berganda merupakan hubungan antara dua atau lebih variabel yaitu variabel bebas (variable independen) dan variabel terikat (variabel dependen).

Persamaan regresi pada penelitian ini dapat dirumuskan sebagai berikut:

$\mathrm{Y}=\mathrm{a}+\beta 1 \mathrm{X} 1+\beta 2 \mathrm{X} 2+\beta 3 \mathrm{X} 3+\mathrm{e}$

Di mana:

$\mathrm{Y} \quad=$ Variabel terikat (Proses Keputusan Pembelian)

a $\quad=$ Konstanta

$\beta 1, \beta 2, \beta 3=$ Koefisien Regresi

$\mathrm{X}_{1} \quad=$ Variabel $\mathrm{X}_{1}$ (Store Atmosphere)

$\mathrm{X}_{2} \quad=$ Variabel $\mathrm{X}_{2}$ (Kualitas Produk)

$\mathrm{e} \quad=$ Error term. 


\section{Uji Instrumen Penelitian \\ Uji Validitas}

Instrumen yang valid berarti alat ukur yang digunakan untuk mendapatkan data (mengukur) itu valid. Valid berarti instrument tersebut dapat digunakan untuk mengukur apa yang seharusnya diukur. Item yang mempunyai korelasi positif dengan kriterium (skor total) serta korelasi yang tinggi, menunjukkan bahwa item tersebut mempunyai validitas yang tinggi pula (Sugiyono, 2010).

\section{Uji Reliabilitas}

Sugiyono (2012) menyatakan instrumen yang reliabel adalah instrumen yang bila digunakan beberapa kali untuk mengukur objek yang sama, akan menghasilkan data yang sama. Pengujian reliabilitas instrumen dilakukan dengan menggunakan metode Cronbach'sAlpha. Cronbach'sAlpha sangat cocok digunakan pada skor berbentuk skala (misal 1-4, 1-5) atau skor rentang

\section{Uji Hipotesis}

Uji F digunakan untuk mengetahui apakah secara simultan koefisien variabel bebas mempunyai pengaruh nyata atau tidak terhadap variabel terikat. Pengujian ini dilakukan dangan cara membandingkan $p$-value dengan alpha cronbach $(\alpha)$.

Uji t digunakan untuk mengetahui apakah masing-masing variabel bebas secara parsial memiliki pengaruh signifikan terhadap variabel terikat. Pengujian ini dilakukan dengan cara membandingkan $p$-value dengan alpha cronbach $(\alpha)$. Apabila $p$-value $<\alpha$ $(0,05)$, maka secara parsial atau individual variabel bebas berpengaruh signifikan terhadap variabel terikat, begitu juga sebaliknya.

\section{Koefisien Determinasi $\left(\mathbf{R}^{2}\right)$}

Koefisien determinasi $\left(\mathrm{R}^{2}\right)$ pada intinya mengukur seberapa jauh kemampuan model dalam menerangkan variasi variabel terikat. Nilai koefisien determinasi adalah antara nol dan satu. Nilai $\left(\mathrm{R}^{2}\right)$ yang kecil berarti kemampuan variabel-variabel terikat amat terbatas. Sedangkan, nilai yang mendekati satu berarti variabel-variabel bebas memberikan hampir semua informasi yang dibutuhkan untuk memprediksi variasi variabel terikat. Selain itu koefisien determinasi dipergunakan untuk mengetahui presentase perubahan variabel terikat (Y) yang disebabkan oleh variabel bebas $(\mathrm{X})$.

\section{HASIL DAN PEMBAHASAN}

\section{Uji Validitas}

Berdasarkan uji validitas yang telah dilakukan, hasilnya menyatakan bahwa setiap indikator variabel mengahsilkan korelasi yang besar lebih dari 0,1779 dengan kata lain, instrument penelitian ini berjumlah 24 pertanyaan dalam 120 kuesioner dinilai telah mampu mengukur apa yang sebenarnya diukur dalam penelitian ini.

\section{Uji Reabilitas}

Uji reabilitas ini dilakukan oleh peneliti dengan cara menghitung nilai cronback alpha melalui program SPSS. Variabel tersebut dikatakan reliable jika hasil dari cronback alpha >0,6 dan hasil dari cornback alpha < 0,6 maka variabel tersebut dikatakan tidak reliable (Ghozali, 2006). Berdasarkan hasil analisis yang telah dilakukan, maka hasil pengujian reabilitas semua variable reliable. 


\section{Rangkuman Tabulasi Jawaban Responden}

Tabel 1. Rangkuman Tabulasi Responden

\begin{tabular}{|l|c|c|}
\hline Dimensi & Rata-rata Skor & Kategori \\
\hline Store atmosphere & 427 & Tinggi \\
Kualitas produk & 470,25 & Tinggi \\
\hline Keputusan pembelian & 478,25 & Tinggi \\
\hline Jumlah & $1.375,5$ & \\
Rata-rata & 458,5 & Tinggi \\
\hline
\end{tabular}

Sumber : Data Kuisioner yang diolah, (2019/2020)

Berdasarkan pada tabel 5.10 dapat diketahui bahwa secara keseluruhan rata- rata pada variabel Keputusan pembelian pada J.CO Donuts \& Coffee di Kota Jambi total ratarata keseluruhan sebesar 458,5 yang termasuk dalam kategori tinggi.

\section{Analisis Regresi Berganda}

Berdasarkan hasil analisis dengan menggunakan program SPSS versi 21, diperoleh hasil analisis regresi berganda sebagai berikut.

Tabel 2. Hasil uji analisi regresi berganda Coefficients $^{\mathrm{a}}$

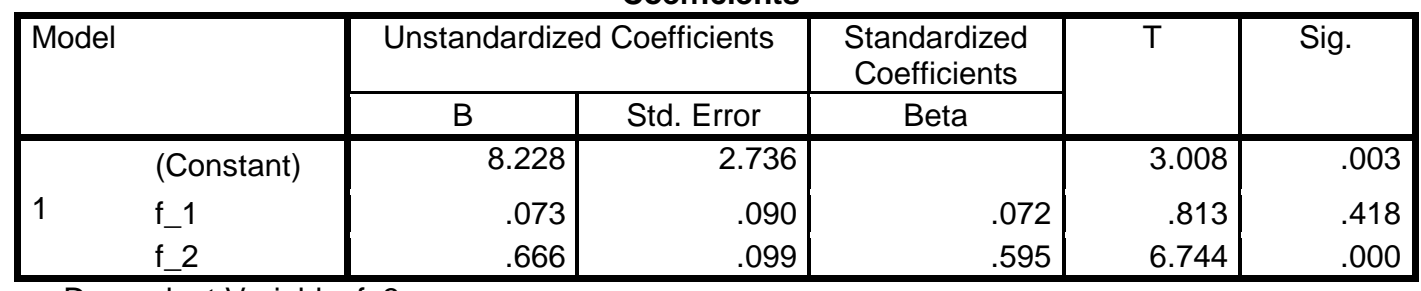

a. Dependent Variable: $f \_3$

Dari hasil analisis program SPSS versi 21 maka dapat diketahui persamaan regresi yang terbentuk. Adapun persamaan regresi linear yang terbentuk adalah:

$Y=8,228+0,073 X_{1}+0,666 X_{2}$

1. Konstanta (a) $=8,228$

Ini berarti jika semua variabel bebas (Pengaruh Store Atmosphere) dianggap sama dengan nol (0) maka nilai variabel terikat (Keputusan Pembelian) sebesar 8,228.

2. Store Atmosphere $\left(\mathrm{X}_{1}\right) 0,073$

Nilai koefisien Store Atmosphere bertanda positif terhadap Keputusan Pembelian dengan nilai koefisien regresi sebesar 0,073 . Hal ini menunjukkan bahwa setiap nilai variabel Store Atmosphere bertambah 1 poin sementara variabel lain diasumsikan tetap, maka variabel Keputusan Pembelian (Y) akan menurun sebesar 0,073.

3. Kualitas produk $\left(\mathrm{X}_{2}\right) 0,666$

Nilai koefisien Kualitas produk bertanda positif terhadap Keputusan Pembelian dengan nilai koefisien regresi 0,666 Hal ini menunjukkan bahwa setiap nilai variabel Kualitas produk bertambah satu poin sementara variabel lain diasumsikan tetap, maka variabel Keputusan Pembelian (Y) akan menurun sebesar 0,666. 


\section{Uji Hipotesis}

\section{Uji F (Uji Simultan)}

Uji F digunakan untuk menunjukkan apakah semua variabel independen atau bebas yang dimasukkan dalam model mempunyai pengaruh secara bersama terhadap variabel dependen atau terikat (Imam,2005). Uji dalam penelitian ini bertujuan untuk mengetahui signifikansi pengaruh dari variabel bebas Store Atmosphere $\left(\mathrm{X}_{1}\right)$, dan Kualitas produk $\left(\mathrm{X}_{2}\right)$, terhadap variabel Proses Keputusan Pembelian (Y) secara simultan. Pengujian ini dilakukan dengan cara membandingkan $p$-value dengan alphacronbach $(\alpha)$. Adapun cara mengambil keputusan untuk penerimaan atau penolakan hipotesis pengaruh secara simultan adalah sebagai berikut.

a) Jika $p$-value $<\alpha(0,05)$, maka $\mathrm{H}_{0}$ ditolak dan $\mathrm{H}_{\mathrm{a}}$ diterima, artinya variabel bebas secara simultan mempunyai pengaruh yang signifikan terhadap variabel terikat.

b) Jika $p$-value $>\alpha(0,05)$, maka $\mathrm{H}_{0}$ diterima dan $\mathrm{H}_{\mathrm{a}}$ ditolak, artinya variabel bebas secara simultan tidak berpengaruh secara signifikan terhadap variabel terikat.

Hasil uji F dalam penelitian ini dapat dilihat pada tabel berikut :

\section{Tabel 3.Hasil uji F}

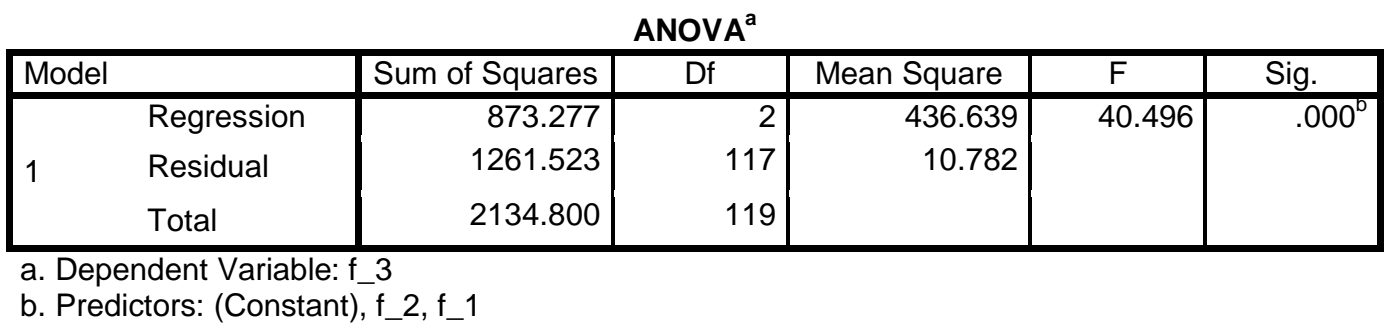

Dari tabel 5.12 diatas dapat dilihat bahwa $p$-value $(0,000)>\alpha(0,05)$. Hal ini berarti $\mathrm{H}_{0}$ diterima dan $\mathrm{H}_{\mathrm{a}}$ ditolak, sehingga dapat disimpulkan bahwa variabel bebas antara lain Store Atmosphere $\left(\mathrm{X}_{1}\right)$, dan Kualitas produk $\left(\mathrm{X}_{2}\right)$, mempunyai pengaruh yang signifikan secara bersama-sama terhadap variabel terikat keputusan pembelian (Y). Dengan kata lain Store Atmosphere, dan Kualitas produk dapat mempengaruhi keputusan pembelian pembelian J.CO Donuts \& Coffee di Kota Jambi. Berdasarkan hasil uji F maka dapat disimpulkan bahwa hipotesis pengaruh Store Atmosphere dan Kualitas produk secara simultan berpengaruh terhadap keputusan pembelian pembelian J.CO Donuts \& Coffee di Kota Jambi sudah terbukti kebenarannya.

\section{Uji t (Uji Parsial)}

Uji t digunakan untuk mengetahui pengaruh masing-masing variabel bebas yaitu Store Atmosphere dan Kualitas produk secara parsial terhadap variabel terikat yaitu Keputusan Pembelian. Pengujian ini dilakukan dengan cara membandingkan $p$-value dengan alphacronbach $(\alpha)$. Adapun cara mengambil keputusan untuk penerimaan atau penolakan hipotesis pengaruh secara parsial adalah sebagai berikut:

a) Jika $p$-value $<\alpha(0,05)$, maka $\mathrm{H}_{\mathrm{a}}$ diterima, artinya variabel bebas secara parsial mempunyai pengaruh yang signifikan terhadap variabel terikat.

b) Jika $p$-value $>\alpha(0,05)$, maka $\mathrm{H}_{\mathrm{a}}$ ditolak, artinya variabel bebas secara parsial tidak berpegaruh secara signifikan terhadap variabel terikat. 
Tabel 4. Hasil Uji t (Uji Pasial)

\begin{tabular}{|c|c|c|c|c|c|c|}
\hline & & & Coefficients & & & \\
\hline \multirow{2}{*}{\multicolumn{2}{|c|}{ Model }} & \multicolumn{2}{|c|}{ Unstandardized Coefficients } & \multirow{2}{*}{$\begin{array}{c}\begin{array}{c}\text { Standardized } \\
\text { Coefficients }\end{array} \\
\text { Beta }\end{array}$} & \multirow[t]{2}{*}{$\mathrm{t}$} & \multirow[t]{2}{*}{ Sig. } \\
\hline & & $\mathrm{B}$ & Std. Error & & & \\
\hline \multirow{3}{*}{1} & (Constant) & 8.228 & 2.736 & & 3.008 & .003 \\
\hline & f_1 & .073 & .090 & .072 & .813 & .418 \\
\hline & $f 2$ & .666 & .099 & .595 & 6.744 & .000 \\
\hline
\end{tabular}

a. Dependent Variable:f_3

Sumber : Pengolahan Data dengan SPSS ver 21(2019/2020)

Berdasarkan hasil pengujian yang telah dilakukan, diperoleh nilai :

a. Store Atmosphere $\left(\mathrm{X}_{1}\right)$ terhadap Keputusan Pembelian (Y)

Berdasarkan pengujian yang telah dilakukan pada tabel 5.13 variabel ini memiliki nilai signifikan yang lebih kecil dari nilai probabilitas $(0,000<0,05)$ Artinya $\mathrm{H}_{0}$ diterima, $\mathrm{Ha}$ ditolak yang berarti variabel Store Atmosphere secara parsial berpengaruh signifikan terhadap Keputusan Pembelian J.CO Donuts \& Coffee di Kota Jambi. Besarnya pengaruh Store Atmosphere terhadap Keputusan Pembelian adalah 0,072 atau 07,2\%. Artinya Store Atmosphere terhadap Keputusan Pembelian 07,2\%.

b. Kualitas produk $\left(\mathrm{X}_{2}\right)$ terhadap Keputusan Pembelian (Y)

Berdasarkan pengujian yang telah dilakukan pada tabel 5.15 variabel ini memiliki nilai signifikan yang lebih besar dari nilai probabilitas $(0,000<0,05)$ Artinya $\mathrm{H} 0$ ditolak, Ha diterima yang berarti secara parsial variabel Kualitas produk $\left(\mathrm{X}_{2}\right)$ signifikan terhadap Keputusan Pembelian Pembelian J.CO Donuts \& Coffee di Kota Jambi.

Selanjutnya diketahui bahwa besarnya pengaruh Kualitas produk terhadap Keputusan Pembelian sebesar 0,595 atau sebesar 59,5\%. Artinya Kualitas produk mampu mempengaruhi Keputusan Pembelian Pembelian sebesar 59,5\%.

Dari kedua nilai antara variabel Store Atmosphere, dan Kualitas produk terdapat perbedaan dimana Variabel Kualitas produk berpengaruh lebih dominan terhadap Keputusan Pembelian disbanding Store Atmosphere.

\section{Koefisien Determinan $\left(R^{2}\right)$}

Untuk melihat besarnya pengaruh variabel bebas terhadap variabel terikat secara keseluruhan dapat dilihat pada tabel model summary berikut ini :

Tabel 5. Hasil Uji Koefisien Determinan $\left(R^{2}\right)$

Model Summary

\begin{tabular}{|l|r|r|r|c|}
\hline Model & $\mathrm{R}$ & $\mathrm{R}$ Square & $\begin{array}{c}\text { Adjusted R } \\
\text { Square }\end{array}$ & $\begin{array}{c}\text { Std. Error of the } \\
\text { Estimate }\end{array}$ \\
\hline 1 & $.640^{\mathrm{a}}$ & .409 & .399 & 3.284 \\
\hline
\end{tabular}

Pada tabel 5.14 diperoleh nilai Adjusted $R$ square sebesar 0,399 = 39,9\%. Ini berarti variabel bebas (Store atmospher dan Kualitas produk) secara bersama-sama mempengaruhi variabel terikat (Keputusan Pembelian) sebesar 39,9\% dan sisanya 60,1\% dipengaruhi oleh variabel lain yang tidak masuk dalam penelitian ini. 


\section{PEMBAHASAN}

\section{Model Store Atmosphere Dan Kualitas Produk Dalam Membentuk Keputusan Pembelian Konsumen}

Dari kedua variabel Store Atmosphere $\left(\mathrm{X}_{1}\right)$, dan Kualitas Produk $\left(\mathrm{X}_{2}\right)$ yang paling utama sebagai Keputusan Pembelian J.Co Donuts \& Coffee di Kota Jambi adalah variabel Kualitas Produk $\left(\mathrm{X}_{2}\right)$.

Peningkatan yang terjadi pada bisnis kuliner tidak lain karena berubahnya gaya hidup masyarakat atau konsumen diIndonesia. Banyaknya bisnis kuliner yang berkembang merupakan suatu perwujudan dalam memenuhi kebutuhan dan keinginan konsumen. Kini konsumen membeli kuliner bukan hanya sekedar untuk menghilangkan lapar ataupun haus saja, namun ada alasan lain seperti mengikuti trend, mencari kenyamanan, dan lainnya. Konsumen pun semakin kritis dalam melakukan pembelian, maka dari itu pebisnis kuliner dituntut untuk dapat kreatif dan inovatif dalam menjalankan bisnisnya. Tidak hanya sekedar memikirkan rasa dari makanan atau minuman yang dijual, namun juga perlu memperhatikan keunikan menu, kenyamanan tempat, kehigienisan makanan atau minuman, dan lainnya sehingga dapat menarik konsumen untuk melakukan pembelian.

Adanya perubahan gaya hidup masyarakat dapat dimanfaatkan oleh para produsen untuk meraup keuntungan semakin besar. Dalam menghadapi persaingan ini maka pengusaha yang bergerak dibidang makanan dan minuman atau Food dan Beverage (F dan B) berlomba-lomba menciptakan keunggulan untuk mendorong produknya tetap bertahan didalam persaingan yang semakin kompetitif. J.CO Donuts \& Coffee melakukan penataan ruang sebaik mungkin untuk menciptakan suasana Gerai yang nyaman saat konsumen menikmati hidangan yang dipesan dan produk yang bisa memuaskan pelanggan.

Selain store atmosphere, kualitas produk juga dapat menjadi pertimbangan konsumen untuk datang berkunjung. Dengan kualitas produk membuat konsumen akan tertarik untuk berkunjung. Kualitas produk yang ditawarkan akan menambah daya tarik konsumen untuk datang berkunjung karena mendapatkan produk makanan yang berkualitas sehingga konsumen mendapat rasa makanan yang enak sekaligus tempat yang nyaman akan membuat konsumen merasa terpuaskan hingga memunculkan minat untuk berkunjung kembali. Jika konsumen merasa puas, konsumen akan melakukan keputusan pembelian ulang. Maka dari itu perusahaan berusaha membuat konsumen puas dengan cara membangun store atmosphere yang bagus maupun kualitas produk yang baik.

Pengaruh Store atmosphere dan kualitas produk dianggap memiliki pengaruh terhadap keputusan pembelian konsumen. Hal ini didukung dengan adanya penelitian terdahulu yang telah dilakukan oleh Okky Khairurrizky (2012) dalam jurnal yang meneliti "Pengaruh storeatmosphere terhadap keputusan pembelian konsumen pada Clio Cafe\&Resto Bandung" mengatakan bahwa store atmosphere memiliki pengaruh terhadap keputusan pembelian. Store atmosphere merupakan suasana yang terencana yang disesuaikan dengan pasar sasarannya sehingga dapat menarik konsumen untuk membeli. Selain itu, Adityas Agung Wicaksono (2012) dan Dahmiri, D., \& Bhayangkari, S. K. W. (2020) mengatakan bahwa store atmosphere terbukti memiliki pengaruh terhadap keputusan pembelian dan kepuasan konsumen.

Suasana toko yang disesuaikan dengan karateristik pribadi seseorang akan menciptakan pengaruh yang berbeda-beda. Sehingga dapat dikatakan bahwa semakin baik pengelolaan suasana toko maka akan semakin menarik konsumen untuk melakukan pembelian pada toko tersebut. Dengan demikian dapat disimpulkan bahwa suasana toko 
yang diatur dengan baik dapat berpengruh positif terhadap peningkatan keputusan pembelian konsumen.

Dalam jurnal Melvern Tamunu and Ferdinand Tumewu (2014), Kualitas produk berpengaruh positif dan signifikan terhadap keputusan pembelian. Hasil ini menunjukkan bahwa penilaian yang baik mengenai kualitas produk yang sesuai dengan tingkat advokasi konsumen akan merangsang konsumen untuk membeli produk tersebut. Hasil ini menunjukkan bahwa penilaian yang baik dari kualitas produk sesuai dengan tingkat keinginan untuk mendorong konsumen untuk membeli produk tersebut. Hasil ini juga menjelaskan bahwa hasil dari pengalaman konsumen dalam menggunakan produk akan menghasilkan penilaian konsumen dari produk. Jika produk dapat memuaskan keinginan konsumen maka konsumen akan memberikan penilaian positif dari produk. Dengan penilaian ini, konsumen masih akan bersedia membeli produk.

Hasil ini menjelaskan bahwa dalam konsumen umum akan menghabiskan uang mereka di rekening untuk kualitas yang dapat diperoleh dari uang yang akan dibelanjakan. Dengan demikian, konsumen akan mempertimbangkan kualitas produk sebagai pengorbanan pertukaran bahwa konsumen menggunakan uang untuk membeli suatu produk. Data empiris dari penelitian ini menunjukkan bahwa produk ini dinilai oleh konsumen memiliki kemampuan untuk menjaga kualitas produk.

Pengaruh Store atmosphere dan kualitas produk dianggap memiliki pengaruh terhadap keputusan pembelian konsumen. Hal ini didukung dengan adanya penelitian terdahulu yang telah dilakukan oleh Nandi Eko Putra (2010) yang memiliki hasil bahwa bahwa suasana toko dan kualitas produk mempunyai pengaruh yang signifikan terhadap minat beli konsumen pada Wadezig Distro Padang secara parsial dan simultan atau bersama-sama.

Selain itu hal ini juga didukung dengan penelitian terdahulu yang dilakukan oleh Rosy Rosmawanti (2016) yang hasil penelitiannya menunjukan bahwa store atmosphere secara parsial memiliki pengaruh terhadap loyalitas konsumen dan kualitas poduk secara parsial memiliki pengaruh terhadap loyalitas konsumen pada Distro House of Smith Buah Batu Bandung.

Jadi semakin baik kualitas produk dan semakin konsumen merasa nyaman maka semakin tinggi pula keputusan pembelian yang akan dilakukan oleh konsumen. Sehingga store atmosphere dan kualitas produk dapat secara bersama-sama mempengaruhi konsumen agar melakukan pembelian dan dapat membuat konsumen berminat berkunjung ulang. Maka dengan semakin baiknya suasana yang diberikan dan semakin baik pula kualitas produk yang ditawarkan semakin tinggi juga minat beli konsumen.

\section{Keputusan Pembelian J.CO Donuts \& Coffee di Kota Jambi}

Suasana toko yang menarik dan kualitas produk yang baik dapat menjaring konsumen sebanyakbanyaknya, dengan kata lain perusahaan dapat menarik keputusan pembelian konsumen agar konsumen tersebut menjadi pelanggan loyal. Pengertian keputusan pembelian, menurut kotler dan keller (2008) adalah tahap dalam proses pengambilan keputusan pembeli di mana konsumen benar-benar membeli. Pengambilan keputusan merupakan suatu kegiatan individu yang secara langsung terlibat dalam mendapatkan dan mempergunakan barang yang ditawarkan.

Menurut Kotler Dan Keller (2008), keputusan pembelian yang dilakukan oleh para konsumen melalui lima tahap yaitu: pengenalan kebutuhan, pencarian informasi, evaluasi alternative, keputusan pembelian, dan perilaku pasca pembelian. Jelaslah bahwa proses pembelian dimulai jauh sebelum pembelian actual dilakukan dan memiliki dampak yang 
lama setelah itu. Namun para para konsumen tidak selalu melewati seluruh lima urutan tahap ketika membeli produk.

Hasil penelitian ini sejalan dengan penelitian terdahulu yang telah dilakukan oleh Lily Harlina Putri (2014) Jurnal Administrasi Bisnis yang meneliti "Pengaruh Store atmosphere terhadap keputusan pembelian dan kepuasan pelanggan (studi pada monopoli cafe dan resto seokarno hatta malang) Hasil penelitian menunjukan bahwa store atmosphere memiliki pengaruh signifikan terhadap keputusan pembelian dan kepuasan pelanngan monopoli cafe dan resto soekarno hatta malang.

Okky Khairurrizky (2012) Jurnal Ilmu dan Riset Manajemen yang meneliti "Pengaruh store atmosphere terhadap keputusan pembelian konsumen pada (Clio Cafe\&Resto Bandung) Hasil penelitian membuktikan bahwa store atmosphere memiliki pengaruh signifikan terhadap keputusan pembelian konsumen pada Clio Cafe\&Resto Bandung.

Bahwa Model store atmosphere dan Kualitas produk secara parsial memiliki pengaruh yang positif dan signifikan terhadap proses keputusan pembelian J.CO Donuts \& Coffee di Kota Jambi.

Reddy Radiyanto (2015) Jurnal Ekonomi dan Komunikasi yang meneliti "Pengaruh store atmosphere dan keragaman produk terhadap loyalitas konsumen (Hayo Cafe Magelang) Hasil penelitian store atmosphere dan keragaman produk memiliki pengaruh terhadap loyalitas konsumen Hayo Cafe Magelang.

Yuliana Sinaga (2012) Jurnal Pendidikan Tata Niaga yang meneliti Pengaruh kualitas pelayanan dan kualitas produk terhadap keputusan pembelian pada (Cafe Its Milk Sidoarjo) Hasil penelitian pada kualitas pelayanan dan kualitas produk memiliki pengaruh terhadap keputusan pembelian pada Cafe Its Milk Sidoarjo.

Esti Wulansari dan Tri Sudarwanto (2014) Jurnal Pendidikan Tata Niaga yang meneliti "Pengaruh cafe atmosphere dan harga terhadap keputusan pembelian pada (Pos Shop Coffee Toffee Simpang) Hasil penelitian membuktikan bahwa cafe atmosphere memiliki pengaruh terhadap keputusan pembelian pada Pos Shop Coffee Toffee Simpang.

Kemal Yildirim, Kubulay Cagatay, Mehmet Lutfi Hidayetoglu (2015) Journal internasional of Retail \& Distribution Management yang meneliti"The effect of age, gender and education level on customer evaluations of retail furniture store atmospheric attributes. Hasil penelitian bahwa efek dari usia, jenis kelamin dan pendidikan di persepsi pelanggan berkenaan dengan store atmosphere.

Riaz Hussain \& Mazhar Ali (2015) International Journal of Marketing Studies yang berjudul "Effect of Store Atmosphere on Consumer Purchase Intention. Temuan penelitian ini menunjukkan bahwa variabel atmosfer seperti kebersihan, aroma, pencahayaan, dan tampilan atau layout memiliki pengaruh positif pada niat pembelian konsumen ; sedangkan musik dan warna memiliki dampak signifikan pada niat pembelian konsumen. Suhu hampir tidak berdampak pada niat pembelian konsumen.

Adapun kesimpulan dari penelitian terdahulu Model store Atmosphere dan Kualitas produk secara parsial memiliki pengaruh yang positif dan signifikan terhadap keputusan pembelian J.CO Donuts \& Coffee di Kota Jambi.

\section{SIMPULAN DAN SARAN}

\section{Simpulan}

1. Secara parsial terdapat pengaruh Store Atmosphere secara signifikan terhadap keputusan pembelian J.CO Donuts \& Coffee dikota jambi dengan nilai parsial variabel Store Atmosphere $\left(\mathrm{X}_{1}\right)$ 0,072 atau 7,2\%. 
2. Secara parsial terdapat pengaruh Kualitas Produk secera signifikan terhadap keputusan pembelian J.CO Donuts \& Coffee dikota jambi dengan nilai parsial 0,595 atau 59,5\%.

3. variabel Store Atmosphere $\left(\mathrm{X}_{1}\right)$, dan Kualitas Produk $\left(\mathrm{X}_{2}\right)$, mempunyai pengaruh yang signifikan secara bersama-sama (simultan) terhadap variabel terikat proses keputusan pembelian (Y). Dengan kata lain Store Atmosphere dan Kualitas Produk dapat mempengaruhi proses keputusan pembelian pembelian J.CO Donuts \& Coffee di Kota Jambi.

4. Dari variabel store atmosphere dan variabel kualitas produk yang paling domonan mempengaruhi keputusan pembelian J.CO Donuts \& Coffee dikota jambi adalah kualitas produk. Hal ini diakibatkan oleh nilai signifikan variabel kualitas produk pada saat dilakukan uji t (parsial) nilainya lebih dominan dari store atmosphere yaitu sebesar $0,595 \%$ atau 59,5\%. Dimana artinya pembelian terbesar didapatkan dari variabel kualitas produk.

\section{Saran}

Disarankan kepada pihak manajemen J.CO Donuts \& Coffee dapat melakukan peningkatan variabel Store Atmosphere $\left(\mathrm{X}_{1}\right)$, terutama pada bagian pencahayaan warna lampu yang dipilih sebagai dekorasi ruangan yang lebih menarik lagi, dimana hasil penelitian mengenai warna lampu yang dipilih tidak mendapat respon yang baik terhadap keputusan pembelian konsumen J.CO Donuts \& Coffee tabulasi tanggapan responden mengenai warna lampu yang dipilih hanya mendapat skor 130 yaitu sangat rendah. Jadi dengan adanya peningkatan pada variabel Store Atmosphere $\left(\mathrm{X}_{1}\right)$ trutama pada pencahayan lampu yang lebih baik diharapkan menambah keputusan pembelian konsumen J.CO Donuts \& Coffee dikota jambi.

Selanjutnya disarankan pada variabel kualitas produk $\left(\mathrm{X}_{2}\right)$, agar tetap dipertahankan. Variabel kualitas produk memiliki nilai rata-rata 470,25 termasuk dalam kategori tinggi, akan tetapi pada variabel kualitas produk perluh menambah porsi donat agar dapat menjadi lbih baik.. Hal ini peneliti sarankan karena pada tabulasi Kualitas produk skor nilai terendahnya adalah 424 dimana "Porsi donuts di J.co sudah sesuai dengan porsi saya." dimana pada pertanyaan ini skor paling rendah dibandingkan dengan skor nilai ditabulasi Kualitas produk lainnya.

Pada penelitian ini terdapat keterbatasan dan kekurangan, disarankan untuk penelitian selanjutnya melakukan penelitian yang lebih mendalam lagi mengenai Store Atmosphere dan Kualitas produk dengan menambah variabel independen serta melalukan penelitian pada obyek yang berbeda sehingga mendapatkan hasil penelitian yang lebih baik lagi.

\section{DAFTAR PUSTAKA}

Dahmiri, D., \& Bhayangkari, S. K. W. (2020). Pengaruh Store Atmosphere, Etika Bisnis dan Kualitas Produk Terhadap Kepuasan Konsumen. Eksis: Jurnal Ilmiah Ekonomi dan Bisnis, 11(1), 1-5.

Esti. (2014). Pengaruh cafe atmosphere terhadap keputusan pembelian gen y pada Old Bens Cafe. Jurnal Manajemen Maranatha, 16(2), 133-144.

Ferdinand, A. (2006). Metode penelitian manajemen.

Fahmi, I. (2016). Manajemen Sumber Daya Manusia Teori dan Aplikasi. Bandung: Alfabeta.

Gummesson, E. (2011). Total relationship marketing. Routledge. 
Griffin (2013). Perilaku Pembelian Online Produk Fashion Pada Zalora Indonesia. Jurnal Sosioteknologi, 15(2), 291-297.

Hasan, D. K. (2015). Pengaruh Kualitas Produk dan Merek Terhadap Keputusan Pembelian Smartphone Merek Iphone Pada Mahasiswa Ilmu Administrasi Niaga/Bisnis FISIP USU. Jurnal Niaga \& Bisnis (e-journal), 2(2).

Hair, J. F. dkk. 2006. Multivariate Data Analysis.

Mullins Jr, J. W. dan Walker Jr, Orville C. (2013). Marketing Management: A Strategic Decision-Making Approach, 8th Edition. McGraw-Hill International Edition.

Kotler, P. (2013). A framework for marketing management. Pearson Education India.

Kotler, P., \& Armstrong, G. (2013). Principles of Marketing (16th Global Edition).

Kotler, P., \& Keller, K. L. (2016). Marketing management (15th global ed.). England: Pearson.

Kotler, P., \& Armstrong, G. (2008). Principles of marketing. 12. painos. New Jersey, Person Education Inc

Lovelock, C. Gummesson. 2011. Pemasaran Jasa.

Mullins Jr, J. W. dan Walker Jr, Orville C. (2013). Marketing Management: A Strategic Decision-Making Approach, 8th Edition. McGraw-Hill International Edition.

Sugiyono, D. (2008). Metode penelitian bisnis. Bandung: Pusat Bahasa Depdiknas.

Sugiyono, (2012). Metode Penelitian Pendahuluan. Alfabeta, Bandung..

Sugiyono, H. (2016). Metode kualitatif dan kuantitatif. Cetakan ke-23. Alfabeta, Bandung. Sangadji, E. M. Sopiah. 2013. Perilaku Konsumen. CV. Andi Offset. Yogyakarta.

Sunyoto, D. (2012). Dasar-dasar manajemen pemasaran. Yogyakarta: Caps. 